\title{
STRATEGI PENGEMBANGAN KAWASAN DALAM MENDUKUNG PENINGKATAN DAYA SAING ANTAR KECAMATAN DI KABUPATEN KULON PROGO
}

\author{
Oleh: \\ Usaji Maulana ${ }^{1}$ dan Nurhadi ${ }^{2}$ \\ ${ }^{1}$ Mahasiswa S2 Pendidikan Geografi Universitas Negeri Yogyakarta \\ ${ }^{2}$ Staf Pengajar Jurusan Pendidikan Geografi FIS UNY \\ usaji_maulana@yahoo.com
}

\begin{abstract}
Abstrak
Penelitian ini bertujuan: (1) mengetahui potensi penduduk, interaksi wilayah, dan Indeks Daya Saing Wilayah (IDSW) dalam menentukan Wilayah Prioritas Pengembangan (WPP) untuk mendukung peningkatan daya saing antar kecamatan (2) menyusun arahan/strategi pengembangan masing-masing WPP dengan memperhatikan keunggulan Daya Saing Wilayah. Pengumpulan data dengan observasi dan dokumentasi. Analisis data dengan analisis potensi penduduk, interaksi wilayah, IDSW, dan Sistem Informasi Geografi. Hasil penelitian: (1) potensi penduduk tertinggi pada Kecamatan Nanggulan untuk bagian utara, Kecamatan Pengasih untuk bagian tengah, dan Kecamatan Lendah untuk bagian selatan. Nilai interaksi wilayah tertinggi bagian utara diantara Kecamatan NanggulanGirimulyo, bagian tengah diantara Kecamatan Pengasih-Sentolo, dan bagian selatan diantara Kecamatan Galur-Lendah. Peringkat IDSW bagian utara adalah Kecamatan Nanggulan, bagian tengah Kecamatan Sentolo, dan bagian selatan Kecamatan Wates. (2) arahan/strategi pengembangan: (a) Bagian Utara sebagai Kawasan Minapolitan Agropolitan dan Pariwisata, (b) Bagian Tengah untuk peningkatan sektor jasa dan industri, (c) Bagian Selatan sebagai daerah industri batik, pengembangan perkotaan, dan pusat pengembangan utama Kabupaten.
\end{abstract}

Kata kunci: Wilayah Prioritas Pengembangan, Indeks Daya Saing Wilayah

\begin{abstract}
This research aims at: (1) determining a demography potency, region interaction, and Regional Competitiveness Index ( $\mathrm{RCl}$ ) in deciding the Priority Development Areas (PDA) to support increased competitiveness among districts, (2) formulating developmental strategies for each PDA by considering the excellence Regional Competitiveness. The data were collected through observations and documentations. Data analysis was performed by analyzing the demography potency, the interaction region, $\mathrm{RCl}$ and Geographic Information Systems. The findings show that: (1) the highest demography potency in the north part is Nanggulan District, the center is Pengasih District, and the south is Lendah District. Moreover, the highest value of region interaction in the northern part is in between Girimulyo and Nanggulan, the center is in between Sentolo and Pengasih, and the south is in between Lendah and Galur. RCl highest ranking in the northern part is Nanggulan District, the center is Sentolo, and the southern part is Wates. (2) The developmental strategies are as follows: (a) Agropolitan, Minapolitan, and Tourism for the Northern part, (b) service and industry for the central part, and (c) batik industry areas, urban development, and main development center district for the southern part.
\end{abstract}

Keywords: Priority Development Area, Regional Competitiveness Index 


\section{PENDAHULUAN}

Peningkatan kualitas Sumber Daya Manusia (SDM) sangat diharapkan sebagai usaha pembangunan bangsa dan negara. Salah satu usaha meningkatkan kualitas SDM yaitu melalui sekolah. Di sekolah, kualitas SDM ditingkatkan melalui pendidikan, di mana pendidikan merupakan transfer of learning yakni proses membelajarkan siswa agar mampu menerapkan ilmu yang didapat dalam kehidupan sehari-hari.

Seiring dengan pelaksanaan Otonomi Daerah, setiap daerah dituntut untuk lebih meningkatkan potensi-potensi yang dimilikinya dalam rangka peningkatan perekonomian dan daya saing daerah tersebut. Peningkatan daya saing wilayah (DSW) ini perlu dilakukan guna meraih sukses pembangunan di masing-masing wilayah yang hakekatnya bertujuan untuk menciptakan kesejahteraan rakyat diseluruh lapisan masyarakat. Kemampuan masing-masing daerah untuk meningkatkan daya saing wilayahnya memang cukup beragam, hal ini diduga terkait dengan perbedaan latar belakang demografi, geografi, infrastruktur, ekonomi, kapasitas sumber daya, dan lain-lain.

Kabupaten Kulon Progo merupakan salah satu kawasan yang perlu dikembangkan dalam rangka meningkatkan daya saing daerah. Dalam pengembangan kawasan di Kabupaten Kulon Progo yang memiliki 12 kecamatan memiliki potensi yang berbeda antar kecamatan dan bila dikembangkan akan menaikkan daya saing kabupaten, propinsi bahkan nasional di mata internasional. Secara kewilayahan, Kabupaten Kulon Progo terletak pada posisi yang menguntungkan. Kabupaten Kulon Progo terletak pada jalur tranportasi Jawa Selatan yang terhubung dengan kota-kota di Jawa oleh jaringan transportasi darat. Jalur selatan Jawa ini memiliki prospek baik untuk berkembang. Prospek ini juga didukung oleh kekayaan sumberdaya wilayah di bidang pertanian, peternakan, perikanan, kelautan, wisata, pertambangan pada masing-masing kecamatan. Wilayah Kabupaten Kulon Progo bagian utara dan barat yang merupakan kawasan perbukitan dengan pemandangan yang elok menyimpan kekayaan di bidang pertanian, perkebunan dan pariwisata (RPJPD Kabupaten Kulon Progo 2005-2025, 2005: 38). Selain itu juga terdapat rencana pembangunan mega proyek yang ada di Kabupaten Kulon Progo seperti Penambangan Pasir Besi, Kawasan Industri Baja di Kecamatan Galur, Panjatan dan Lendah, Bandara Internasional di Kecamatan Temon dan Kawasan Industri Sentolo yang akan saling mendukung daya saing Kabupaten Kulon Progo (Pemkab Kulon Progo, 2011: ).

Kabupaten Kulon Progo memiliki topografi yang bervariasi yaitu dengan ketinggian antara 0-1000 meter di atas permukaan air laut dibagi menjadi tiga wilayah meliputi:

a. Bagian Utara

Bagian utara merupakan dataran tinggi/perbukitan dengan ketinggian antara 500-1000 meter dari permukaan air laut, meliputi wilayah Kecamatan Girimulyo, Kokap, Kalibawang, Nanggulan dan Samigaluh.

b. Bagian Tengah

Bagian tengah merupakan daerah perbukitan dengan ketinggian antara 100-500 meter dari permukaan air laut, meliputi Kecamatan Sentolo, Pengasih, dan Kokap.

c. Bagian Selatan 
Bagian selatan merupakan dataran rendah dengan ketinggian 0-100 meter dari permukaan air laut, meliputi Kecamatan Temon, Wates, Panjatan, Galur, dan Lendah. (BPS, 2012: 3).

Sementara itu penentuan Wilayah Prioritas Pengembangan (WPP) dapat digunakan sebagai upaya optimalisasi sumberdaya yang dimiliki oleh suatu wilayah. Melalui optimalisasi sumberdaya yang dimiliki suatu wilayah, maka pembangunan akan berjalan dengan baik dan menciptakan kesejahteraan umum. Untuk mengoptimalkan nilai manfaat sumberdaya yang berlimpah tetapi tidak merata bagi pengembangan wilayah secara berkelanjutan dan menjamin kesejahteraan umum secara luas (public interest), diperlukan intervensi kebijakan dan penanganan khusus oleh pemerintah untuk pengelolaan wilayah yang tertinggal (Menkimpraswil, 2003: 2). Di samping itu masalah kemiskinan di Kabupaten Kulonprogo masih menjadi persoalan krusial yang harus mendapat perhatian penuh dari pemerintah. Persoalan tersebut adalah masih tingginya angka kemiskinan yang mencapai $24,65 \%$. Angka ini lebih tinggi dibandingkan dengan angka kemiskinan propinsi DIY yang hanya 17,23\% dan Indonesia 14,15\% (Suparjan dan Sugeng Wiyono, 2011: ).

Persoalan lain yang cukup menonjol adalah terjadinya disparitas spasial antar wilayah yang peruntukannya juga terjadi konflik kepentingan dalam penggunaan kawasan (kawasan produktif atau kawasan konservasi). Kondisi ini memunculkan persoalan mengapa angka kemiskinan di daerah tersebut masih cukup tinggi sementara potensi daerah dan sumberdaya alamnya cukup potensial (Suparjan dan Sugeng Wiyono, 2011: ). Oleh karena itu, strategi pengembangan perlu dilakukan dengan cara melihat potensi penduduk antar kecamatan. Pada hakikatnya analisis keruangan (spatial) adalah analis lokasi yang menitikberatkan pada tiga unsur geografi yaitu jarak atau distance, kaitan atau interaction, dan gerakan atau movement (Bintarto dan Surastopo, 1991: 74). Dengan demikian analisis spasial merupakan cara yang dapat dilakukan untuk melakukan kajian pengembangan wilayah terutama dalam menentukan WPP. Analisis semacam ini memperhatikan faktor penduduk dan faktor jarak. Kemampuan indera penglihatan yang terbatas untuk mengamati kenampakan geografis di suatu wilayah atau permukaan bumi, sesorang memerlukan alat bantu (auxiliary toll). Peranan model visualisasi permukaan bumi dan ketersediaan alat bantu seperti peta sangat diperlukan kehadirannya. Pembuatan peta dapat diungkapkan secara jelas dengan bantuan Sistem Informasi Geografi (SIG) yang saat ini sangat popular penggunaannya.

Dimungkinkan hanya dengan melihat analisis keruangan tidaklah cukup maka salah satu caranya dengan melihat Indeks DSW (IDSW). Salah satu metode pengukuran daya saing yang dapat digunakan adalah metode yang merupakan perpaduan dari metode Global Competitiveness Index $(\mathrm{GCl})$ dan Regional Competitiveness Index (RCl) melalui beberapa pilar penentu seperti Kelompok Pilar Dasar seperti Kondisi Makroekonomi,Infrastruktur, Kesehatan, dan Pendidikan; Kelompok Pilar Efisiensi seperti Ketenagakerjaan dan Ukuran Pasar; Kelompok Pilar Inovasi seperti Ketersediaan Teknologi, dan Kemudahan Berusaha (Disnakertrans DIY, 2011: 6). Suatu daerah yang mampu bersaing dengan daerah lain dalam memproduksi dan memasarkan barang dan jasanya disebut mempunyai daya saing tinggi (Christanto, 2011: 51). 


\section{METODE}

Berdasarkan tujuannya, penelitian ini merupakan penelitian deskriptif, yaitu penelitian yang menggambarkan dan menganalisis potensi penduduk, interaksi wilayah, dan IDSW yang dimiliki masing-masing kecamatan sebagai acuan dalam menentukan WPP serta arahan/strategi yang mampu mendukung kegiatan pengembangan wilayah di Kabupaten Kulon Progo. Penelitian ini dilakukan dengan cara mengumpulkan dan menganalisis data skunder dari instansi yang relevan serta didukung oleh pengamatan langsung di lapangan

Subjek penelitian dalam penelitian ini yaitu seluruh kecamatan di Kabupaten Kulon Progo. Jumlah kecamatan di Kabupaten Kulon Progo berjumlah 12 kecamatan. Penelitian ini dilaksanakan di Kabupaten Kulon Progo Daerah Istimewa Yogyakarta pada Bulan Januari hingga Bulan Maret 2013. Teknik pengumpulan data dalam penelitian ini antara lain: Observasi dan Dokumentasi. Penelitian ini menggunakan teknik analisis spasial berupa potensi penduduk, interaksi wilayah (Bintarto dan Surastopo, 1991: 80-82) dan SIG dengan analisis query dan klasifikasi. Analisis IDSW dengan metode Global Competitiveness Index (GCl) dan Regional Competitiveness Index (RCl).

\section{HASIL DAN PEMBAHASAN}

\section{Penentuan Wilayah Prioritas Pengembangan (WPP)}

Penentuan wilayah Prioritas Pengembangan (WPP) mengacu pada nilai potensi penduduk dan Indeks Daya Saing Wilayah (IDSW). Nilai interaksi antar wilayah digunakan untuk melihat kecenderungan penduduk dalam berinteraksi dengan wilayah terdekat untuk melakukan aktivitas sosial, ekonomi, maupun keagamaan. Penentuan WPP menggunakan dua metode yang berbeda yaitu analisis keruangan (analisis potensi penduduk dan interaksi penduduk) dan analisis IDSW. Hasil analisis menunjukkan potensi penduduk tertinggi berada pada Kecamatan Nanggulan untuk bagian utara (Sub-SWP I) yang mempunyai nilai 1.566,52, Kecamatan Pengasih untuk bagian tengah (Sub-SWP II) dengan nilai 2.045,53, dan Kecamatan Lendah untuk bagian selatan (Sub-SWP III) dengan nilai sebesar 44.410,43. Hasil dari analisis potensi penduduk dan IDSW dapat dilihat pada Tabel 1 dan 2 serta posisi spasialnya ditunjukkan oleh Gambar 1 dan Gambar 2 berikut ini:

Tabel 1. WPP Berdasarkan Analisis Potensi Penduduk

\begin{tabular}{|l|l|c|c|}
\hline \multicolumn{1}{|c|}{ Sub-SWP } & \multicolumn{1}{|c|}{ Wilayah } & $\begin{array}{c}\text { Nilai Potensi } \\
\text { Penduduk }\end{array}$ & Skor \\
\hline Bagian Utara & Nanggulan & $1.566,52$ & 1 \\
\hline Bagian Tengah & Pengasih & $2.045,53$ & 1 \\
\hline Bagian Selatan & Lendah & $44.410,43$ & 1 \\
\hline
\end{tabular}

Sumber: Hasil Analisis, 2013 
Tabel 2. WPP Berdasarkan Analisis IDSW

\begin{tabular}{|l|l|c|c|}
\hline \multicolumn{1}{|c|}{ Sub-SWP } & \multicolumn{1}{|c|}{ Wilayah } & $\begin{array}{c}\text { Nilai } \\
\text { IDSW }\end{array}$ & Skor \\
\hline Bagian Utara & Nanggulan & 4,35 & 1 \\
\hline Bagian Tengah & Sentolo & 4,33 & 1 \\
\hline Bagian Selatan & Wates & 5,39 & 1 \\
\hline
\end{tabular}

Sumber: Hasil Analisis, 2013

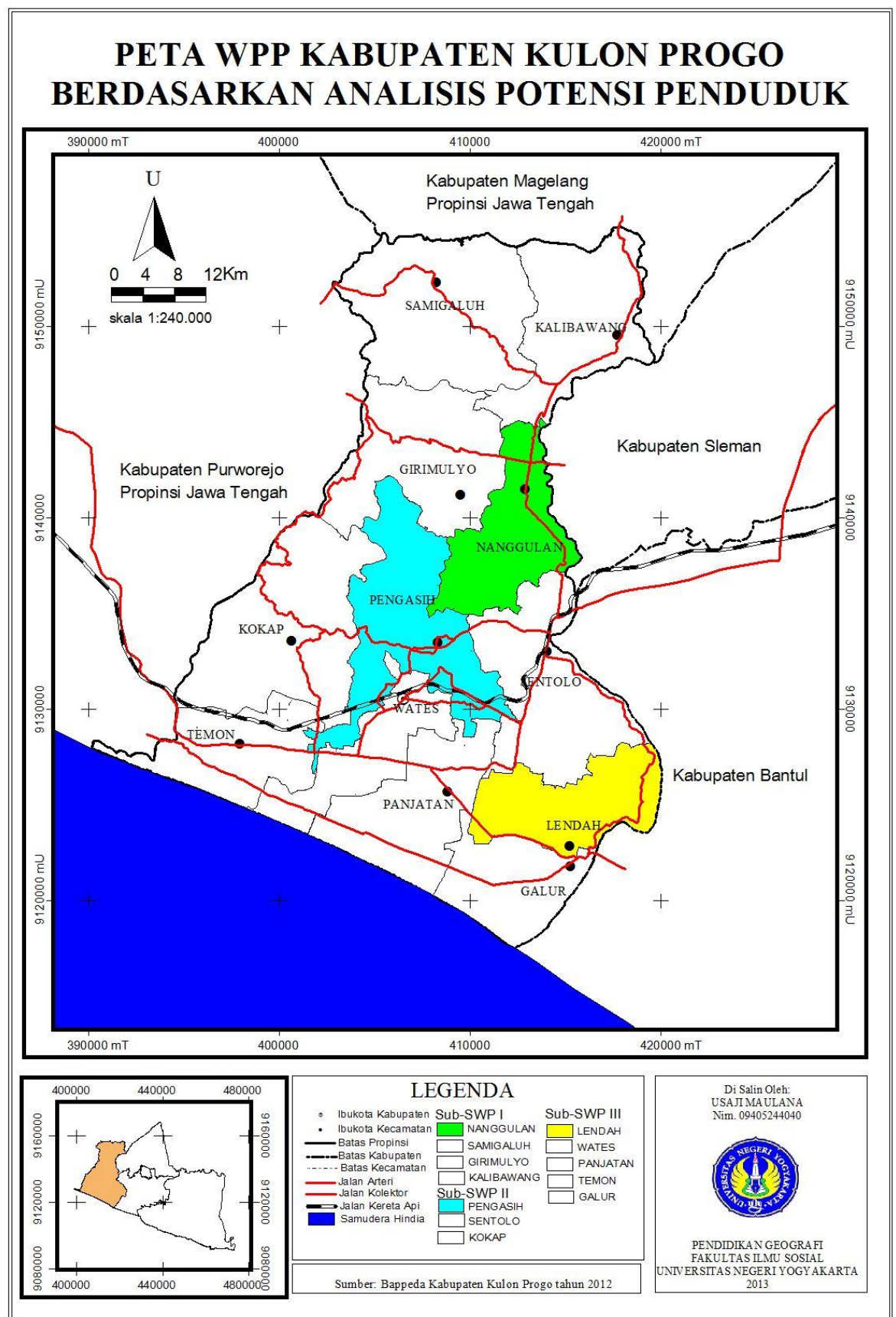

Gambar 1. Peta WPP Kabupaten Kulon Progo Berdasarkan Analisis Potensi Penduduk 


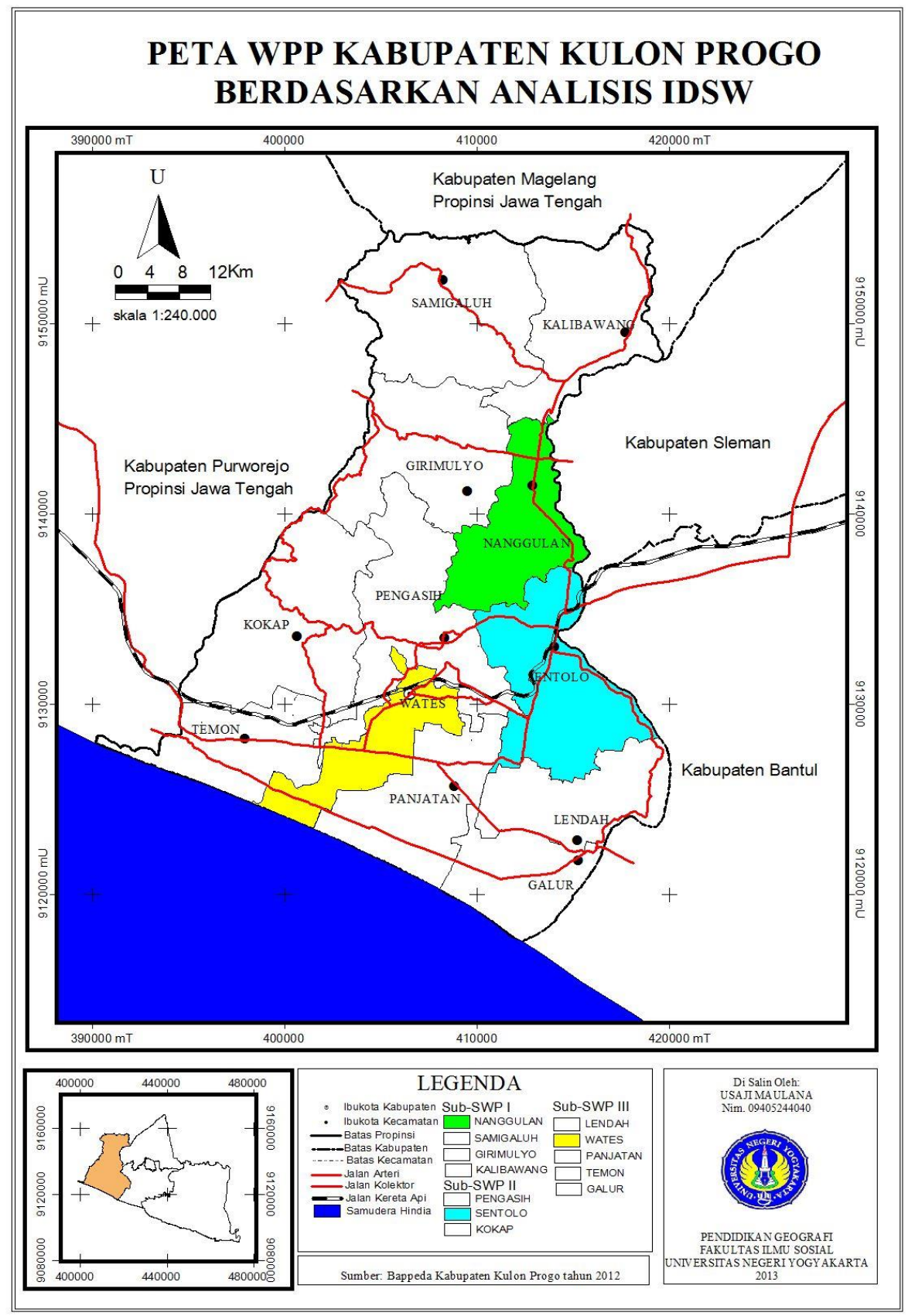

Gambar 2. Peta WPP Kabupaten Kulon Progo Berdasarkan Analisis IDSW

Hasil analisis menggunakan nilai interaksi penduduk, setiap WPP berkecenderungan melakukan interaksi dengan wilayah terdekat. Pada jalur interaksi, wilayah-wilayah tersebut lebih cepat berkembang dibanding dengan wilayah yang berada jauh dari jalur tersebut. Wilayah Kecamatan Nanggulan di bagian utara (Sub-SWP I) cenderung berinteraksi lebih besar dengan Kecamatan Girimulyo. Kedua wilayah ini cukup padat penduduk dan jarak keduanya relatif dekat jika dibandingkan wilayah lainnya dalam Sub-SWP I. Wilayah Kecamatan Pengasih di bagian tengah (Sub-SWP II) lebih mudah berinteraksi dengan Kecamatan Sentolo karena berada pada jalur perhubungan darat yang 
strategis yakni dilewati jalan kabupaten dan jalan nasional. Jarak antar kedua kecamatan ini yang relatif dekat dan jumlah penduduk yang besar juga memungkinkan kecenderungan interaksi semakin tinggi. Kecamatan Galur di Bagian Selatan (Sub-SWP III) lebih besar interaksinya terhadap Kecamatan Lendah di sebelah utaranya. Hal ini dipengaruhi oleh jarak yang hanya dua $\mathrm{km}$ sehingga kedua kecamatan ini dalam berinteraksi sangat mudah, baik segi kerjasama antar wilayah berupa kegiatan pertanian, industri maupun jasa-jasa (Tabel 3 dan Gambar 3).

Tabel 3 WPP Berdasarkan Nilai Interaksi

\begin{tabular}{|l|l|c|c|}
\hline \multicolumn{1}{|c|}{ Sub-SWP } & \multicolumn{1}{c|}{ Interaksi } & Nilai Interaksi & Skor \\
\hline Bagian Utara & Nanggulan-Girimulyo & $4.126 .070,3$ & 1 \\
\hline Bagian Tengah & Pengasih-Sentolo & $16.623 .279,9$ & 1 \\
\hline Bagian Selatan & Galur-Lendah & 265.334 .160 & 1 \\
\hline
\end{tabular}

Sumber: Hasil Analisis, 2013

\section{PETA INTERAKSI WILAYAH ANTAR KECAMATAN DI KABUPATEN KULON PROGO}

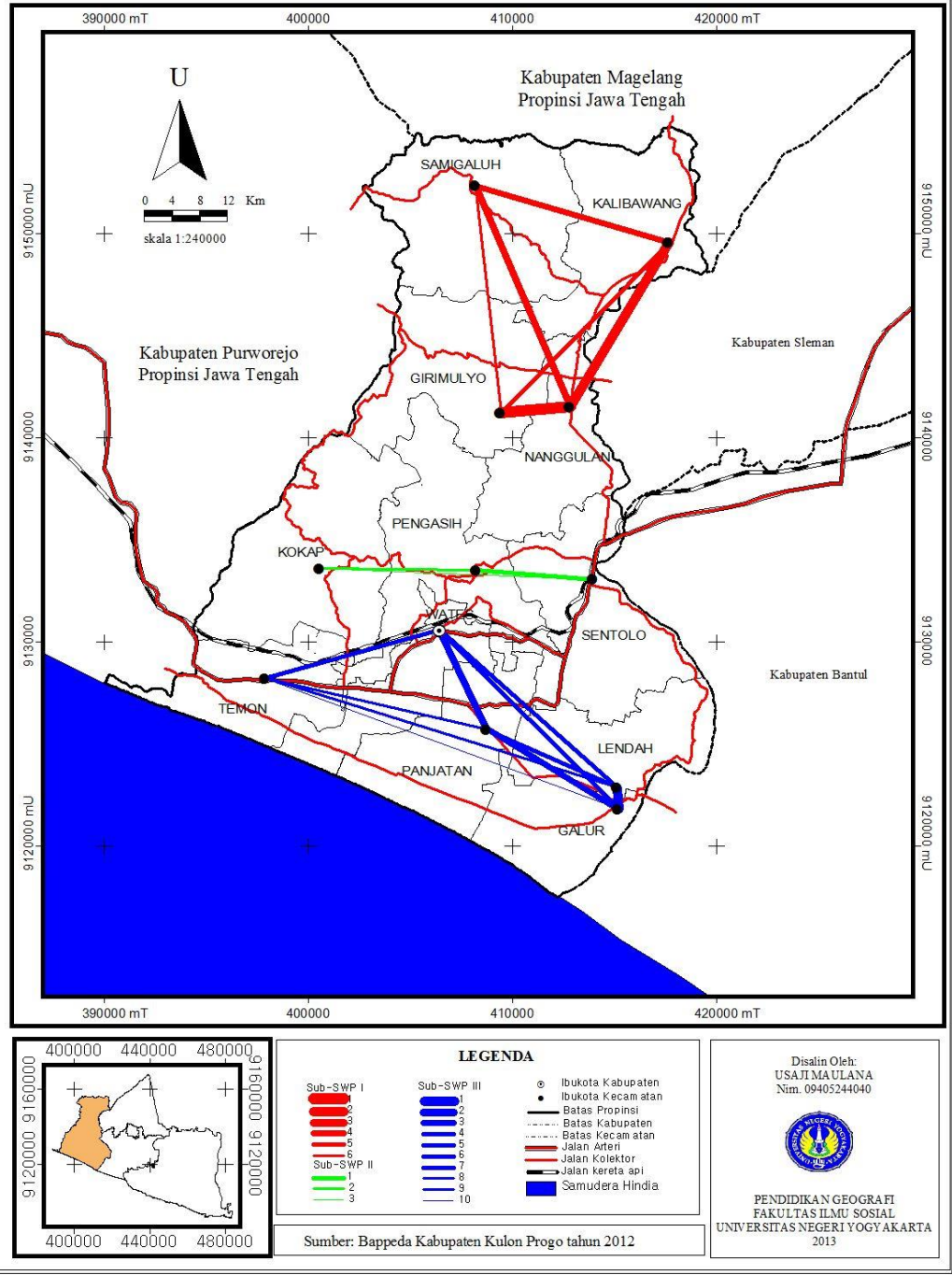

Gambar 3. Peta Interaksi Wilayah Antar Kecamatan di Kabupaten Kulon Progo 


\section{Arahan Pengembangan Wilayah Prioritas Pengembangan}

Setelah melakukan penentuan pusat-pusat pertumbuhan dengan melakukan pengolahan data sekunder, tahap selanjutnya adalah menentukan prioritas pengembangan bagi wilayah-wilayah pusat pertumbuhan sesuai dengan potensi yang dimiliki oleh masingmasing wilayah kecamatan pusat pertumbuhan.

Arah dan strategi pengembangan mengacu pada RTRW Kabupaten Kulon Progo yaitu arahan pemanfaatan ruang wilayah, dengan prioritas pengembangan. Sebagai kecamatan unggulan, Kecamatan Nanggulan pada bidang pertumbuhan ekonomi sebagai kawasan minapolitan dengan luas kurang lebih 7.160 (tujuh ribu seratus enam puluh) hektar. Kecamatan Nanggulan mempunyai keunggulan pada nilai potensi penduduk dengan jumlah penduduk terbanyak di bagian utara. Pada kelompok Pilar Dasar Kecamatan Nanggulan masih kurang, terutama pada Pilar Infrastruktur dan Pendidikan. Modal fisik berupa infrastruktur baik ketersediaan maupun kualitasnya mendukung aktivitas ekonomi daerah. Pilar Infrastrutur dan pendidikan, Kecamatan Nanggulan dapat bekerjasama dengan Kecamatan Samigaluh yang memiliki pilar infrastruktur yang tinggi menurut analisis IDSW dan dapat bekerjasama dengan Kecamatan Sentolo yang jaraknya lebih dekat.

Kecamatan yang memiliki nilai potensi penduduk dan nilai interaksi penduduk tertinggi, Kecamatan Pengasih mempunyai keunggulan sektor jasa dan sektor industri. Peningkatan sektor jasa terutama sektor pariwisata, contohnya: Yayasan Konservasi Alam Yogyakarta (YKAY), pemandian clereng dan makanan Geblek. Kecamatan Pengasih mempunyai sumber/mata air untuk dikonsumsi yang dimanfaatkan oleh PDAM Kabupaten Kulon Progo untuk memproduksi air minum SEHAT, dengan penetapan Gerakan Bela Kulon Progo dan Beli Kulon Progo merupakan salah satu bentuk kemandirian sosial ekonomi daerah dimana sedapat mungkin perekonomian warga di Kabupaten Kulon Progo dicukupi oleh hasil produksi lokal. Nilai interaksi penduduk yang tinggi dengan Kecamatan Sentolo akan mempermudah proses transportasi yang berupa jasa, ekonomi, pendidikan dan lainnya. Interaksi dengan Ibukota Kabupaten dengan jarak yang cukup dekat membantu kegiatan perekonomian, pendidikan dan kesehatan.

Pengembangan Kecamatan Sentolo diarahkan menjadi kawasan industri. Keunggulan Kecamatan Sentolo, yaitu dilalui oleh jalan nasional dan lintasan kereta api akan mempermudah sektor industri, jasa dan perdagangan. Arah pengembangannya terutama pada sektor sumber daya manusia, yaitu: ketersediaan dan kualitas sumber daya manusia yang berupa angkatan kerja dalam jumlah besar dan berkualitas, pelatihan dan pendidikan, sikap dan nilai yang dianut oleh tenaga kerja, kualitas hidup masyarakat akan meningkatkan dan menentukan daya saing daerah.

Kecamatan Lendah memiliki nilai potensi penduduk dan nilai interaksi yang tertinggi. Dengan keunggulan ini akan membantu Kecamatan Lendah dalam meningkatkan kesejahteraan masyarakatnya, sebagai daerah industri pembuatan batik, pengembangan industri batik Geblek Renteng. Kemandirian sebuah masyarakat dapat dicapai ketika ada perubahan pola pikir masyarakat untuk mencintai dan lebih banyak menggunakan produk utamanya dari dalam daerah sendiri. 
Pengembangan Perkotaan Wates sebagai pusat Pemerintahan Daerah dan pusat pengembangan utama Kabupaten. Sebagai Kecamatan yang mempunyai daya saing yang tinggi, fungsi dari Kecamatan Wates adalah menciptakan iklim persaingan yang sehat sehingga potensi-potensi daerah dapat muncul secara maksimal selain itu efektivitas pemerintah daerah dalam menyediakan infrastruktur dan aturan-aturan (persetujuan dan larangan) dalam pembangunan daerah berpengaruh terhadap daya saing ekonomi suatu daerah. Situasi keamanan yang kondusif juga akan memperlancar aktivitas ekonomi, sosial dalam upaya pengembangan kawasan untuk mreningkatkan daya saing. Kecamatan yang berada di bagian selatan atau daerah pesisir ini juga mempunyai banyak potensi antara lain potensi pariwisata, pertanian, perikanan, dan industri. Rencana pembangunan Bandar udara yang berada di Kecamatan Temon akan meningkatkan pendapatan bagi warga sekitar yang berakibat pada kesejahteraan masyarakat.

\section{SIMPULAN}

Setelah melalui tahap pengolahan data, kesimpulan penelitian yaitu pertama, penentuan WPP menurut analisis spasial dilakukan dengan mencari nilai potensi penduduk, interaksi wilayah dan IDSW. Potensi penduduk tertinggi berada pada Kecamatan Nanggulan untuk bagian utara (Sub-SWP I), Kecamatan Pengasih untuk bagian tengah (Sub-SWP II), dan Kecamatan Lendah untuk bagian selatan (Sub-SWP III). Sedangkan nilai interaksi wilayah tertinggi pada bagian utara (Sub-SWP I) berada diantara Kecamatan Nanggulan-Girimulyo, bagian tengah (Sub-SWP II) diantara Kecamatan Pengasih-Sentolo, dan pada bagian selatan (Sub SWP III) diantara Kecamatan Galur-Lendah. Untuk peringkat IDSW, Kecamatan Nanggulan pada bagian utara (Sub-SWP I), Kecamatan Sentolo pada bagian tengah (Sub-SWP II), dan Kecamatan Wates pada bagian selatan (Sub-SWP III). Besarnya potensi penduduk dan IDSW ini menjadi dasar dalam penentuan WPP disetiap Sub-SWP.

Kedua, berdasarkan identifikasi arahan/strategi pengembangan WPP yang terpilih di Kabupaten Kulon Progo meliputi Menyusun strategi pengembangan masing-masing WPP yang harus dilakukan dengan memperhatikan keunggulan DSW (a) Bagian Utara, Kecamatan Nanggulan, arah pengembangan sebagai Kawasan Minapolitan, Agropolitan dan Pariwisata, (b) Bagian Tengah, Kecamatan Pengasih diarahkan untuk peningkatan sektor jasa dan industri, Kecamatan Sentolo diarahkan menjadi Kawasan Industri terutama pengembangan ketenagakerjaan, (c) Bagian Selatan, Kecamatan Lendah memiliki nilai potensi penduduk yang tinggi, dengan nilai interaksi yang tinggi pula akan membantu kecamatan Lendah dalam meningkatkan kesejahteraan, sebagai daerah industri pembuatan batik, Pengembangan Perkotaan Wates dengan memaksimalkan sebagai pusat Pemerintahan Daerah dan pusat pengembangan utama Kabupaten.

\section{SARAN}

saran-saran yang diajukan berdasarkan hasil penelitian antara lain: (1) meningkatkan dan mengembangkan potensi sektoral yang sesuai dengan kemampuan dan prioritas pengembangan masing-masing kecamatan di Kabupaten Kulon Progo untuk 
meningkatkan DSW. Meningkatkan dan mengembangkan peranan kecamatan pusat pertumbuhan di Kabupaten Kulon Progo agar dapat menjalankan peranannya dalam meningkatkan DSW terutama lebih mengutamakan peranan Sub-SWP I, II dan III sehingga mampu menstimulus perkembangan kecamatan disekitarnya. (2) kerjasama antar daerah merupakan satu kunci penting dalam meningkatkan daya saing daerah secara khusus dan pembangunan regional secara umum terutama dalam upaya meningkatkan kemampuan daerah pada bidang industri, perdagangan dan jasa selain pertanian sebagai pendapatan utama. Selain daerah yang yang diunggulkan daerah yang tingkat daya saing yang rendah perlu juga dikembangkan, dengan cara daerah yang memiliki potensi dan daya saing tinggi secara bersama-sama meningkatkan daya saing kecamatan yang rendah, selain itu saling mendukung antar kecamatan yang memiliki daya saing tinggi sehingga akan meningkatkan kesejahteraan masyarakat. (3) merealisasikan rencana pembangunan Bandar udara yang berada di Kecamatan Temon di bagian selatan Kabupaten Kulon progo ini akan meningkatkan pendapatan bagi warga Kulon Progo yang akan berdampak pada kesejahteraan masyarakat.

\section{UCAPAN TERIMA KASIH}

Tulisan ini merupakan bagian dari penelitian tugas akhir skripsi yang berjudul Kajian Strategi Pengembangan Kawasan Dalam Rangka Mendukung Peningkatan Daya Saing Antar Kecamatan Di Kabupaten Kulon Progo. Dalam kesempatan ini penulis mengucapkan terima kasih yang sebesar-besarnya kepada berbagai pihak yang telah membantu dalam proses penelitian, khususnya kepada pembimbing tugas akhir.

\section{DAFTAR PUSTAKA}

Bintarto dan Surastopo Hadisumarno. (1991). Metode Analisa Geografi. Jakarta: LP3ES. BPS. (2011). Kulon Progo dalam Angka 2012. Kulon Progo: BPS Kabupaten Kulon Progo.

Christanto, J. (2011). Membangun Daya Saing Daerah melalui Penciptaan Kompetensi Inti daerah. Yogyakarta: Deepublish.

Disnakertrans Provinsi DIY. (2011). "Pengukuran dan pembahasan daya saing tingkat kabupaten/kota di Provinsi DIY". Laporan daya saing tingkat kabupaten/kota di Provinsi DIY. HIm. 4

Pemkab Kulon Progo. (2011). Prospektus Peluang Investasi di Kabupaten Kulon Progo. dalam http://kpm.kulonprogokab.go.id/index.php? pilih=news\&mod=yes\&aksi= lihat\&id=1055. Diakses senin, tanggal 05 oktober 2012 pukul 19.00 wib.

Suparjan dan Sugeng Wiyono. (2011). (RPJMD)Kabupaten Kulon Progo. Terdapat di ttp://psppr.ugm.ac.id/seminar/seminar-2011/76-membedah-rencanapembangunan-jangka-menengah-daerah-rpjmd-kabupaten-kulon-progo. Diakses selasa, tanggal 06 oktober 2012 pukul 20.00 wib. 